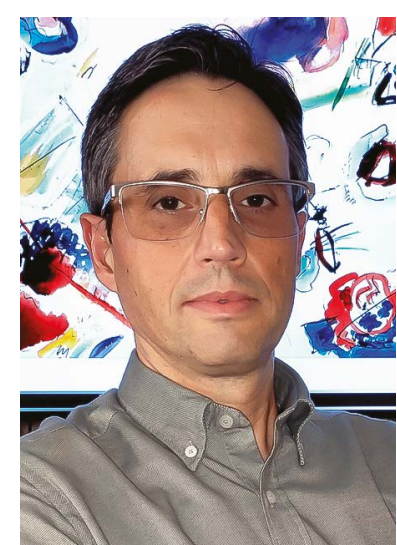

A SPQ está de parabéns. O Presidente da República condecorou a SPQ como Membro Honorário da Ordem da Instrução Pública pelos altos serviços prestados à causa da educação e do ensino, em particular pelo trabalho desenvolvido na promoção da investigação da Química junto dos jovens que frequentam o ensino secundário em Portugal. Trata-se de um reconhecimento que engrandece uma Sociedade que continuará, com estímulo renovado, a estar atenta às responsabilidades e desafios atuais e a honrar os seus objetivos estatutários de "promover, cultivar e desenvolver, em Portugal, a investigação, o ensino e a aplicação da Química e das Ciências com esta mais diretamente relacionadas".

O QUÍMICA, enquanto principal meio de informação impresso da SPQ, é parte ativa na prossecução destes objetivos. Torna-se, pois, oportuno renovar o pedido para que sócios, Delegaações, Divisões e Grupos da SPQ e outros leitores do QUÍMICA tenham uma participação ativa nos seus conteúdos através do envio de propostas de textos para publicação. $\mathrm{Na}$ submissão de artigos para revisão por pares existe uma oportunidade para que, de uma forma mais didática ou de divulgaçãa, se possa dar uma panorâmica da investigaçãa na área da Química (ou em áreas onde a Química desempenha um papel relevante) que se faz no nosso país ou conhecer o trabalho dos investigadores portugueses no estrangeiro. Textos vocacionados para a área do Ensino e História da Química são também relevantes. Numa altura em que as ações de formação da SPQ para professores têm tido bastante procura, é importante que se divulguem conteúdos que possam ser úteis para esses docentes. Os artigos submetidos ao QUÍMICA são atualmente pré-publicados online (b-quimica.spq.pt/manuscritos-aceites) assim que aceites para publicação. 0 sistema DOI, recentemente implementado para todos os conteúdos, permite dar uma maior visibilidade, alcance e impacto aos textos publicados. Neste contexto, convida-se o leitor a visitar a nova página web do QUÍMICA (b-quimica.spq.pt). Mais apelativa, permite uma navegação imediata pelos conteúdos da publicação.

Neste número, um conjunto de autores elegeu o QUÍMICA para divulgar o seu trabalho. Fala-se do papel dos MOFs no diagnóstico de vírus, de como a natureza continua a ser uma fonte importante para a obtenção de moléculas e materiais com elevado interesse científico e tecnológico, do papel da química analítica na identificação da origem de derrames petrolíferos e dos desafios que se colocam no tratamento de águas oleosas contaminadas. A Interação Química mostra que nos devemos orgulhar da investigacção química que realizamos em Portugal há mais de um século e da herança recebida dos antigos professores portugueses de química.

Numa altura em que se está a iniciar um novo ano letivo, que se pretende dentro da normalidade, felicitamos todos os alunos que concorreram e entraram no ensino superior em cursos de química ou em áreas relacionadas. A procura por estes cursos foi significativa, o que demonstra o contínuo interesse pela Ciência Central por parte dos jovens. 0 papel dos professores que os acompanharam durante os seus percursos académicos e que naturalmente contribuíram para este resultado deve ser igualmente valorizado. Quem sabe, se os novos alunos não seguirão as pisadas de químicos de renome, como é o caso dos recém laureados com o prémio Nobel da Química Benjamin List e David W. C. MacMillan. Porque... Pelo sonho é que vamos, / Comovidos e mudos. / Chegamos? Não chegamos? / Haja ou não frutos, / Pelo Sonho é que vamos. / Basta a fé no que temos. I Basta a esperança naquilo / Que talvez não teremos. / Basta que a alma demos, / Com a mesma alegria, / Ao que desconhecemos / E ao que é do dia-a-dia. / Chegamos? Não chegamos? / -Partimos. Vamos. Somos. ("Pelo Sonho é que Vamos", Sebastião da Gama).

$>$

Paulo Mendes
BOLETIM DA SOCIEDADE PORTUGUESA DE QUÍMICA PROPRIEDADE DE SOCIEDADE PORTUGUESA DE QUÍMICA

NIPC: 501139265

ISSN $0870-1180$

Registo na ERC n. ${ }^{\circ} 125525$

Depósito Legal n. ${ }^{\circ} 51420 / 91$

Publicação Trimestral

N. ${ }^{\circ} 162$, julho-setembro 2021

REDAÇÃO, EDIÇÃO E ADMINISTRAÇÃO

Av. da República, 45 - 3. ${ }^{\circ}$ Esq. - 1050-187 Lisboa

Tel.: 217934637 • Fax: 217952349

bspq@uevora.pt·www.spq.pt

Diretor: Paulo Mendes

Diretores-adjuntos: Ana Paula Esteves, Bruno Machado, Maria José Lourenço, Marta Piñeiro Gómez, Vasco D.B. Bonifácio

Comissão de Aconselhamento Editorial:

Augusto Tomé, Helder T. Gomes, João Paulo R. F. André, Joaquim L. Faria, Jorge Morgado, Mário N. Berberan-Santos

\section{ESTATUTO EDITORIAL}

Disponível em:

www.spq.pt/boletim/estatuto_editorial

\section{PUBLICIDADE}

Sociedade Portuguesa de Química

secretariado@spq.pt

\section{DESIGN GRÁFICO E PAGINAÇ̃̃o}

Rodrigo Nina

www.rodrigonina.com

rodrigo.pnina@gmail.com

Tel.: 964819822

IMPRESSÃO E ACABAMENTO

Tipografia Lessa

Pta dos Mogos, 157 - Z. Ind. de Vermoim

4470-343 Maia

+351229441603

geral@tipografialessa.pt

Tiragem: 1.500 exemplares

As colaborações assinadas são da exclusiva responsabilidade dos seus autores, não vinculando de forma alguma a SPQ, nem a Direção do QUíMICA. São autorizadas e estimuladas todas as citações e transcrições, desde que seja indicada a fonte, sem prejuízo da necessária autorização por parte do(s) autor(es) quando se trate de colaborações assinadas. As normas de colaboração e as instruções para os autores podem ser encontradas no sítio web da SPQ.

PUBLICAÇ̃̃O SUBSIDIADA PELA FCT

Apoio do Programa Operacional Ciência, Tecnologia, Inovação do Quadro Comunitário de Apoio III 